\title{
The Shine-Dalgarno hybrid during initiation of translation and elongation
}

\author{
D. Maraschio, A. La Teana, P. Volpe ${ }^{1}$ \\ Institute of Biochemistry of the University of Ancona \\ Via Ranieri, 60131 Ancona, Italy \\ ${ }^{1}$ Department of Biology of the University of Rome «Tor Vergata» \\ Via della Ricerca Scientifica 1, 00133 Rome, Italy \\ volpe@bio.uniroma2.it
}

\begin{abstract}
It was unknown whether a synthetic Shine-Dalgarno (SD) oligonucleotide labelled with ${ }^{32} P$ at its 5 '-end ( $\left.{ }^{32} P\right]$ oct $)$ would be able to reach the anti-SD sequence of $16 S$ rRNA at the early stages of translation only or during elongation. To verify this, ${ }^{32}$ P]oct was incubated with $30 S$ ribosomal subunits (RSUS), $70 S$ ribosomes and polysomes, separately, while the SD/anti-SD binding was checked in them through sucrose gradients. The anti-SD sequence resulted highly available in $30 S$ RSUs and sufficiently available in ribosomes. In both $30 S$ RSUs and ribosomes, the addition of a model $002 m R N A$ in equimolar proportions displaced $\left[{ }^{32} P\right]$ oct for about $50 \%$. However, in ribosomes the presence of initiation factors (IFs) and $f M e t-t R N A$ influence neither the binding of $\left[^{32} P\right]$ oct nor the competition coming from $m R N A$. In polysomes, $\left[{ }^{32} P\right]$ oct was unable to hybridize the anti-SD sequence, in agreement with the hypothesis that mRNA and $16 S$ rRNA are involved in the SD/anti-SD interaction also during elongation.
\end{abstract}

Keywords: ribosomal machinery, mRNA/16S rRNA recognition, peptide bond formation, polysomal conformation and translational state.

Introduction. Initiation of protein synthesis in bacteria represents an intriguing process during which the small 30S RSU binds both mRNA and initiator fMet-tRNA to construct a complex which interacts with the large $50 \mathrm{~S}$ RSU. Formation of the first peptide bond between fMet-tRNA in the $P$ site (corresponding to the first mRNA codon) and aminoacyl-tRNA in the $A$ site (corresponding to the second mRNA codon) marks the transition between initiation of translation and elongation. Three IFs $\left(\mathrm{IF}_{1}, \mathrm{IF}_{2}, \mathrm{IF}_{3}\right)$ and one GTP molecule are necessary to ensure efficiency and fidelity of the reactions $[1,2]$.

(C) D. MARASChIO, A. LA TEANA, P. VOLPE, 2007
One of the early events is the recognition, by $30 \mathrm{~S}$ RSU, of the mRNA sequence known as transition initiation region. Its body includes the initiation codon (in most cases AUG), a spacer of variable length and the purine-rich SD sequence (5'-AAGGAGGT-3') complementary to the 3 '-end region of $16 \mathrm{~S}$ rRNA (3'-TTCCTCCA-5') [3]. The base pairing between the SD sequence of mRNA and the anti-SD sequences of $16 \mathrm{~S}$ rRNA is a crucial step in mRNA/ribosome recognition and, consequently, in the process of translation: mutant mRNAs with more extended SD pairing show an increased level of gene expression, but mutant mRNAs with a low extent of base pairing are 
poorly translated $[4,5]$. Alternatively, the capability of mRNAs to be expressed, when they do not carry the SD sequence, suggested that this sequence is not essential for translation [6] and that its main function is to ensure a high concentration of initiation codon near the ribosomal $P$ site [7].

This information shed sufficient light on the role of the SD/anti-SD interaction at the early stages of translation, although it was still unclear if such an interaction would be limited to the early steps of translation initiation only or if $16 \mathrm{~S}$ rRNA and mRNA would also remain in contact during elongation. The latter possibility was supported by two observations: in experiments with hydroxyl-radical footprinting the protection of the SD sequence by ribosome still persists in an elongation complex (70S/mRNA/fMettRNA/Phe-tRNA) [8]; the SD/anti-SD interaction influences the ribosomal frame-shifting [9]. On this basis, it was suggested that the SD base pairing might function by stabilizing the mRNA/ribosome interaction during elongation [9].

The present investigation demonstrated that $\left[{ }^{32} \mathrm{P}\right]$ oct is able to reach the anti-SD sequence of $16 \mathrm{~S}$ rRNA not only in isolated 30S RSUs but also in $70 \mathrm{~S}$ ribosomes, whereas the same anti-SD sequence is inaccessible in polysomes.

Materials and Methods. RSUs, ribosomes and polysomes were isolated from the MRE 600 strain of Escherichia coli [10] with minor modification of the procedures described earlier [11-13]. To purify polysomes, a $60-\mathrm{ml}$ bacterial culture grown to $0.5-0.6$ $\mathrm{OD}$ at $560 \mathrm{~nm}$ was chilled and harvested through a 3 -min centrifugation at $5,000 \mathrm{rev} . / \mathrm{min}$. The precipitated bacteria were reversed in $0.4 \mathrm{ml}$ of $25 \%$ sucrose diluted in $0.01 \mathrm{M}$ Tris- $\mathrm{HCl}$ at $\mathrm{pH} 8.1$. To this sample a $0.1-\mathrm{ml}$ volume of $0.25 \mathrm{M}$ Tris- $\mathrm{HCl}$ at $\mathrm{pH} 8.1$, containing $2.7 \mathrm{mg} / \mathrm{ml}$ ethylen-diamino-tetraacetic acid (EDTA), was added. After 45-sec shaking, it was transferred into a cold centrifuge tube containing a mixture of $100 \mathrm{ml}$ of $0.1 \mathrm{M} \mathrm{MgSO}_{4}, 50 \mathrm{ml}$ of $1 \mathrm{mg} / \mathrm{ml}$ DNAse, $200 \mathrm{ml}$ of $1 \%$ sodium deoxycholate (in $0.1 \mathrm{M}$ Tris- $\mathrm{HCl}$ at $\mathrm{pH} 8.1$ ) and $5 \%$ Brij 58 (in $0.1 \mathrm{M}$ Tris- $\mathrm{HCl}$ at $\mathrm{pH}$ 7.2). Then, the bacterial cells were lysed within $2 \mathrm{~min}$, the lysate was concentrated at 7,000 rev./min for $5 \mathrm{~min}$ and the supernatant, holding the polysomes, was run for $19 \mathrm{hrs}$ at $13,000 \mathrm{rev} . / \mathrm{min}$ through a $15-30 \%$ sucrose gradient performed in a mixture of $5 \mathrm{mM}$ Tris- $\mathrm{HCl}$ at $\mathrm{pH} 7.2,10 \mathrm{mM} \mathrm{MgSO}_{4}$ and $60 \mathrm{mM} \mathrm{KCl}$.

IFs, aminoacyl-tRNAs and T7 RNA polymerase (RNApol). The IFs of translation and the aminoacyl-tRNAs were prepared from $E$. coli essentially according to [1, 12]. The RNApol was purified from the BL 21 strain carrying the $p A R 1219$ plasmid which includes its gene controlled by the tac promoter [14]. The sample was inoculated in $12 \mathrm{ml}$ of defined medium (M9TB). In addition to $1 \mathrm{~g} / \mathrm{N} \mathrm{NH}_{4} \mathrm{Cl}$, $3 \mathrm{~g} / 1 \mathrm{KH}_{2} \mathrm{PO}_{4}, 6 \mathrm{~g} / 1 \mathrm{Na}_{2} \mathrm{HPO}_{4}, 10 \mathrm{~g} / 1$ trypton and $5 \mathrm{~g} / \mathrm{l}$ $\mathrm{NaCl}$, this contained $40 \mathrm{mg} / \mathrm{ml}$ ampicillin, $0.4 \%$ maltose, and $1 \mathrm{mM} \mathrm{MgSO}_{4}$. A hyperproduction of RNApol was induced by $0.4 \mathrm{mM}$ isopropyl-thio$\beta$-D-galactoside. After growing to $0.5 \mathrm{OD}$ at $600 \mathrm{~nm}$, the bacteria were harvested at 7,000 rev./min for 10 min, washed twice with $20 \mathrm{ml}$ of $20 \mathrm{mM}$ Tris- $\mathrm{HCl}$ at $\mathrm{pH}$ 8 (enriched with $20 \mathrm{mM} \mathrm{NaCl}$ plus $1 \mathrm{mM} \mathrm{Na} \mathrm{N}_{2}$ EDTA) and put at $-80{ }^{\circ} \mathrm{C}$. Once frozen, they were resuspended in $15 \mathrm{ml}$ of $50 \mathrm{mM}$ Tris- $\mathrm{HCl}$ at $\mathrm{pH} 8.0$ containing 20 $\mathrm{mM} \mathrm{NaCl}, 2 \mathrm{mM} \mathrm{Na}_{2}$ EDTA, and $6 \mathrm{mM}$ $\beta$-mercaptoethanol (ME). The cell lysis was reached by adding $1.5 \mathrm{mg} / \mathrm{ml}$ lysozyme. The lysate, treated with 24 $\mathrm{ml}$ of $0.1 \mathrm{M}$ phenyl-methyl- sulfonyl-fluorure and 14 $\mathrm{ml}$ of $0.1 \mathrm{M}$ benzamide (to inhibit possible proteases), was left for $20 \mathrm{~min}$ at room temperature. Then, it was mixed with $180 \mathrm{ml}$ of $4 \%$ sodium deoxycholate, prepared in $1 \mathrm{mM} \mathrm{MgCl} 2,3 \mathrm{ml}$ of $2 \mathrm{M}\left(\mathrm{NH}_{4}\right)_{2} \mathrm{SO}_{4}$ and 5 $\mathrm{mg} / \mathrm{ml} \mathrm{DNAse,} \mathrm{and} \mathrm{maintained} \mathrm{for} \mathrm{another} 20 \mathrm{~min}$ at room temperature. The final sample was treated with 30 $\mathrm{ml}$ of a $50 \mathrm{mM}$ Tris- $\mathrm{HCl}$ buffer at $\mathrm{pH} 8$ comprising 20 $\mathrm{mM} \mathrm{NaCl}, 2 \mathrm{mM} \mathrm{Na}{ }_{2}$ EDTA, and $6 \mathrm{mM}$ ME. The RNA and DNA macromolecules were precipitated with 1.5 $\mathrm{ml}$ of $10 \%$ Polymin P. The suspension was stirred in ice for $20 \mathrm{~min}$ and centrifuged at $15,000 \mathrm{rev} . / \mathrm{min}$ for 15 min. Its supernatant was precipitated again with $1.5 \mathrm{ml}$ of $10 \%$ Polymin $\mathrm{P}$, stirred in ice for $15 \mathrm{~min}$ and centrifuged at $15,000 \mathrm{rev} . \mathrm{min}$ for $15 \mathrm{~min}$. The new supernatant was mixed with $\left(\mathrm{NH}_{4}\right)_{2} \mathrm{SO}_{4}$ to reach a concentration of $33 \%$. Thereafter, the solution was centrifuged for $10 \mathrm{~min}$ at $12,000 \mathrm{rev} . \mathrm{min}$, while the pellet was resuspended in $10 \mathrm{ml}$ of $20 \mathrm{mM}$ potassium-phosphate buffer at $\mathrm{pH} 7.7$ combined with $100 \mathrm{mM} \mathrm{NaCl}, 1 \mathrm{mM} \mathrm{Na} 2$ EDTA, $6 \mathrm{mM} \mathrm{ME}$ and $5 \%$ glycerol. The sample was dialysed overnight against $600 \mathrm{ml}$ of the same buffer at $4{ }^{\circ} \mathrm{C}$. The dialysed material 


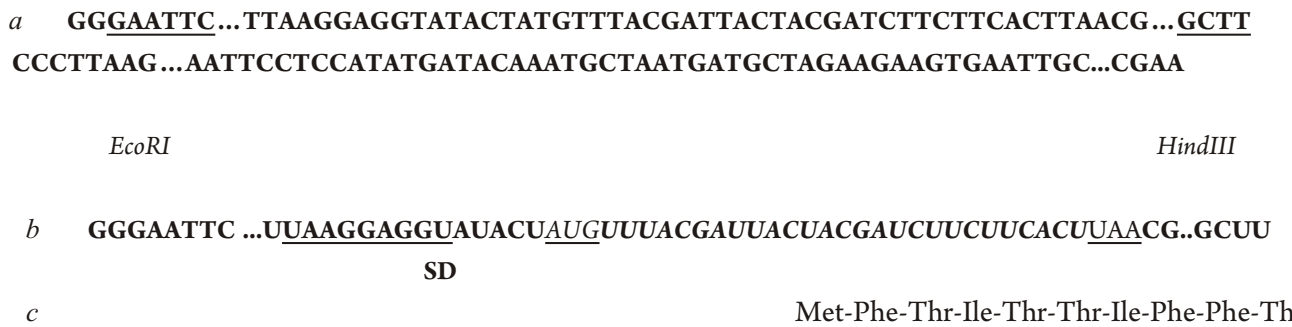

Fig. 1. Model 002 gene integrated in the plasmid pTZ18. (a) Double stranded DNA: the restriction sites for EcoRI and HindIII are underlined. (b) mRNA transcript: the SD sequence, the initiation codon AUG and the stop codon UAA are underlined; the «reading frame» is in italics. (c) Encoded peptide constituted by 10 residues. The dots, in $(a)$ and $(b)$, replace a number of upstream and downstream nucleotides not shown

was centrifuged at $10,000 \mathrm{rev} . \mathrm{min}$ for $10 \mathrm{~min}$ and, in turn, the supernatant was mixed with an equal volume of $20 \mathrm{mM}$ potassium-phosphate at $\mathrm{pH} 7.7$ holding 1 $\mathrm{mM} \mathrm{Na} \mathrm{NDTA}$, $6 \mathrm{mM}$ ME, and $5 \%$ glycerol. The preparation was then percolated through a cation exchanger SP-Sepharose Fast Flow column equilibrated with $20 \mathrm{mM}$ potassium-phosphate buffer at pH 7.7 (in which $10 \mathrm{mM} \mathrm{NaCl}, 1 \mathrm{mM} \mathrm{Na}_{2}$ EDTA, 6 $\mathrm{mM} \mathrm{ME}$ and $5 \%$ glycerol were diluted). Elution of RNApol was obtained using $20 \mathrm{mM}$ potassium-phosphate buffer at $\mathrm{pH} 7.7$ (including 200 $\mathrm{mM} \mathrm{NaCl}, 1 \mathrm{mM} \mathrm{Na} 2$ EDTA, $6 \mathrm{mM} \mathrm{ME}$, and $5 \%$ glycerol), while its yield was monitored by measuring the OD at $280 \mathrm{~nm}$ in the collected fractions. Finally, after overnight dialysis against $200 \mathrm{ml}$ of $20 \mathrm{mM}$ potassium-phosphate buffer at $\mathrm{pH} 7.7$ (mixed with 10 $\mathrm{mM} \mathrm{NaCl}, 1 \mathrm{mM} \mathrm{Na} 2$ EDTA, $6 \mathrm{mM} \mathrm{ME}$, and $5 \%$ glycerol), the homogeneity of the enzyme protein was checked on a $7.5 \%$ sodium dodecylsulphateacrylamide gel.

Transcription and purification of 002 mRNA. Through a minor modification of the procedure proposed by [7], the transcript was made on a plasmid DNA which carried the T7 promoter (Fig. 1). The in vitro reaction lasted $180 \mathrm{~min}$ at $37^{\circ} \mathrm{C}$ in $1-\mathrm{ml}$ volume of $40 \mathrm{mM}$ Tris- $\mathrm{HCl}$ at $\mathrm{pH} 8.1$. In addition to $40 \mathrm{mg} / \mathrm{ml}$ plasmid DNA and $47 \mathrm{mg} / \mathrm{ml} \mathrm{RNApol} \mathrm{[14],} \mathrm{this} \mathrm{buffer}$ contained: $22 \mathrm{mM} \mathrm{MgCl} 2,5 \mathrm{mM}$ spermidine, $5 \mathrm{mM}$ dithiothreitol, $0.1 \mathrm{mg} / \mathrm{ml}$ bovine serum albumine and, at an equimolar $3.75 \mathrm{mM}$ concentration, ATP, GTP, CTP, and UTP. The reaction was stopped with $50 \mathrm{ml}$ of $0.5 \mathrm{M}$ EDTA. After adding $1 \mathrm{ml}$ of $1 \mathrm{M} \mathrm{NaCl}$, the polymerized polyribonucleotide was percolated through an oligo(dT)-cellulose column equilibrated with $20 \mathrm{mM}$
Tris- $\mathrm{HCl}$ at $\mathrm{pH} 7.4$ and $1 \mathrm{mM}$ EDTA. Fractions of $1 \mathrm{ml}$ were collected and tested for OD at $260 \mathrm{~nm}$, while the polymer, dissolved in them, was precipitated at $-20{ }^{\circ} \mathrm{C}$ in the presence of $3 \mathrm{M}$ sodium acetate $(1 / 10$ of the volume) plus $100 \%$ ethanol (2.5 volumes). The solution was centrifuged at $10,000 \mathrm{rev} . / \mathrm{min}$ for $30 \mathrm{~min}$ while, after adding $70 \%$ ethanol, the yielded mRNA was recentrifuged at $10,000 \mathrm{rev} / \mathrm{min}$ for $30 \mathrm{~min}$. Following ethanol evaporation, it was dissolved in water, treated with $0.1 \%$ diethyl-pyrocarbonate, frozen at $-20{ }^{\circ} \mathrm{C}$ and checked for its purification degree on a $10 \%$ polyacrylamide gel with $7 \mathrm{M}$ urea.

Binding of $\left.{ }^{32} P\right]$ oct to $16 S r R N A$. In agreement with [15], the synthetic 5'-AAGGAGGT-3' oligonucleotide (furnished by Eugentec without phosphate group at the 5 '-end) was labelled with ${ }^{32} \mathrm{P}$ released by $\left[\gamma^{32} \mathrm{P}\right] \mathrm{ATP}$ (Amersham) under the action of T4 kinase (GibcoBRL). The reaction mixture had a volume of $10 \mathrm{ml}$ comprising: $70 \mathrm{mM}$ Tris- $\mathrm{HCl}$ at $\mathrm{pH} 7.6,10 \mathrm{mM} \mathrm{MgCl}_{2}$, $0.1 \mathrm{M} \mathrm{KCl}, 1 \mathrm{mM} \mathrm{ME}, 3 \mathrm{ml}\left[\gamma^{-{ }^{32}} \mathrm{P}\right] \mathrm{ATP}(3,000$ $\mathrm{Ci} / \mathrm{mmol}), 10$ units of $\mathrm{T} 4$ kinase and 200 pmoles unlabelled oligonucleotide. The transfer of ${ }^{32} \mathrm{P}$ developed within $45 \mathrm{~min}$ at $37^{\circ} \mathrm{C}$ while, after enzyme inactivation which lasted $10 \mathrm{~min}$ at $68^{\circ} \mathrm{C}$ (followed by freezing at $-20{ }^{\circ} \mathrm{C}$ ), the yield of $\left[{ }^{32} \mathrm{P}\right]$ oct was quantified through denaturing polyacrylamide gel electrophoresis [15]. The interaction of $\left[{ }^{32} \mathrm{P}\right]$ oct with $16 \mathrm{~S}$ rRNA was verified through the sucrose gradient method. Each sample carried 200 pmoles of $\left[{ }^{32} \mathrm{P}\right]$ oct and 100 pmoles of $30 \mathrm{~S}$ RSUs or $70 \mathrm{~S}$ ribosomes or polysomes (when specified, it contained 200 pmoles of mRNA, 100 pmoles of IFs and 100 pmoles of fMet-tRNA or Phe-tRNA). The reactions were performed in $20 \mathrm{mM}$ Tris- $\mathrm{HCl}$ at $\mathrm{pH} 8.1$ enriched with $150 \mathrm{mM} \mathrm{KCl}$ and 15 
$\mathrm{mM} \mathrm{MgCl} 2$. Once incubated at $37^{\circ} \mathrm{C}$ for $10 \mathrm{~min}$ and 10 ${ }^{\circ} \mathrm{C}$ for $30 \mathrm{~min}$, the samples were loaded onto $10-30 \%$ sucrose gradients. These were made in $10 \mathrm{mM}$ Tris- $\mathrm{HCl}$ at $\mathrm{pH}$ 7.7, enriched with $10 \mathrm{mM} \mathrm{Mg}$-acetate and $60 \mathrm{mM}$ $\mathrm{NH}_{4} \mathrm{Cl}$. Centrifugation lasted $2 \mathrm{hrs}$ in the cold at 40,000 rev./min, using the Kontron TST 60.4 rotor. The radioactivity carried by the fractions was measured in the Rackbeta LKB liquid scintillation counter using the Cherenkov radiation channel. Absorbance was determined at $260 \mathrm{~nm}$ in the Beckman DU 640 spectrophotometer after adequate dilution with $10 \mathrm{mM}$ Tris- $\mathrm{HCl}$ at $\mathrm{pH} 7.7$ to which $10 \mathrm{mM} \mathrm{Mg}$-acetate and $60 \mathrm{mM} \mathrm{NH}_{4} \mathrm{Cl}$ were added.

Results and Discussion. It emerged that, in $30 \mathrm{~S}$ RSUs, the amount of $\left[{ }^{32} \mathrm{P}\right]$ oct bound to the anti-SD sequence of $16 \mathrm{~S}$ rRNA gradually increased as a function of its concentration. In fact, the addition of 400 pmoles of $\left[{ }^{32} \mathrm{P}\right]$ oct caused a $60 \%$ SD/anti-SD hybridization (Fig. 2). In 70S ribosomes, the amount of $\left[{ }^{32} \mathrm{P}\right]$ oct bound to the anti-SD sequence of $16 \mathrm{~S}$ rRNA decreased constantly with respect to that observed in 30S RSUs. In this case, the addition of 400 pmoles of $\left[{ }^{32} \mathrm{P}\right]$ oct caused a $40 \% \mathrm{SD} /$ anti-SD hybridization (Fig. 2). Such a difference accounted for a higher availability of the anti-SD sequence of 16S rRNA in 30S RSUs and for its lower availability in $70 \mathrm{~S}$ ribosomes.

Competition between $\left[^{32} P\right]$ oct and $002 \mathrm{mRNA}$ in hybridizing the anti-SD sequence of $16 S$ rRNA in $30 S$ $R S U s$. The hybridization of $\left[{ }^{32} \mathrm{P}\right]$ oct with the anti-SD sequence of $16 \mathrm{~S}$ rRNA was confirmed when in $30 \mathrm{~S}$

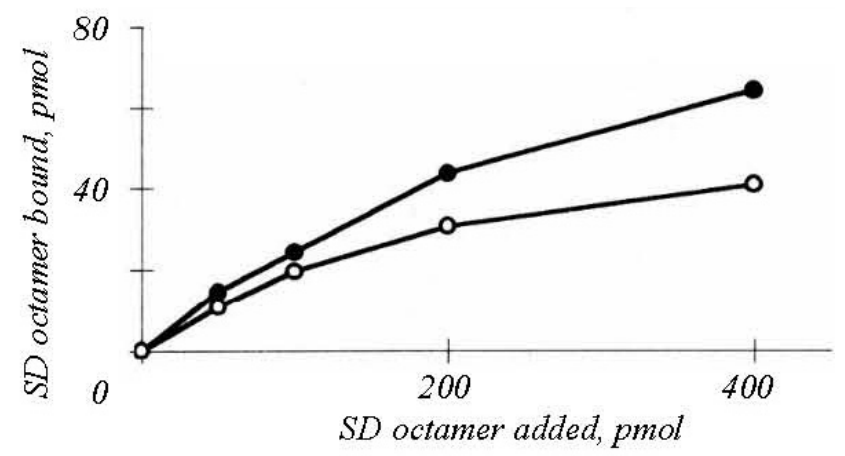

Fig. 2. Kinetics of binding between $\left[{ }^{32} \mathrm{P}\right]$ oct and $30 \mathrm{~S}$ RSUs $v s$. that of binding between $\left[{ }^{32} \mathrm{P}\right]$ oct and $70 \mathrm{~S}$ ribosomes. One hundred pmoles of $30 \mathrm{~S}$ RSUs or $70 \mathrm{~S}$ ribosomes were incubated with 50 to 400 pmoles of $\left[{ }^{32} \mathrm{P}\right]$ oct. The radioactivity bound to $30 \mathrm{~S}$ RSUs (filled circles) and $70 \mathrm{~S}$ ribosomes (empty circles) was detected after their centrifuging through sucrose gradient. The values represent the mean of three experiments

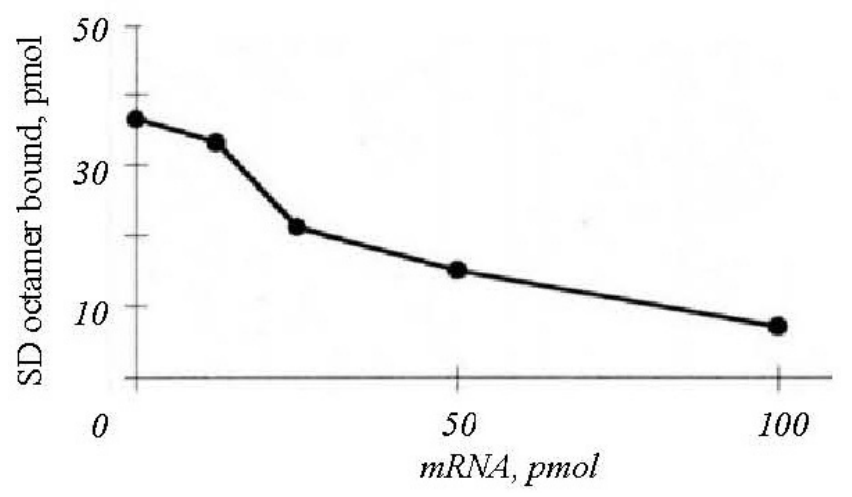

Fig. 3. Competition between $\left[{ }^{32} \mathrm{P}\right]$ oct and $002 \mathrm{mRNA}$ for binding with the anti-SD sequence of $16 \mathrm{~S}$ rRNA. Fifty pmoles of $30 \mathrm{~S}$ RSUs were incubated with 100 pmoles of $\left[{ }^{32} \mathrm{P}\right]$ oct, in the presence of 0 to 100 pmoles of mRNA. The radioactivity bound to $30 \mathrm{~S}$ RSUs was detected after centrifuging through sucrose gradient. The experiment was repeated twice

RSUs it competed with mRNA for the same site. A clear demonstration of this was observed when the amount of bound $\left[{ }^{32} \mathrm{P}\right]$ oct decreased as a function of the mRNA pmoles added to the 30S-RSU samples: the hybridization showed values of about $40 \%$ in the absence of mRNA and values lower than $10 \%$ in the presence of 100 pmoles of mRNA (Fig. 3).

This result was expected, since the first step in the initiation of translation is the building of an aggregate constituted by $30 \mathrm{~S}$ RSU which carries mRNA and fMet-tRNA.

Full availability of the anti-SD sequence in $30 \mathrm{~S}$ $R S U s$. The access to the anti-SD sequence of $16 \mathrm{~S}$ rRNA was further confirmed through three experiments aimed at verifying the direct level of binding radioactivity originating in $\left[{ }^{32} \mathrm{P}\right]$ oct. When the $30 \mathrm{~S}-\mathrm{RSU}$ sample was incubated with $\left[{ }^{32} \mathrm{P}\right]$ oct only, its $11-17$ th sucrose gradient fractions exhibited an extremely high specific labelling (Fig. 4, A). When the 30S-RSU sample was incubated with $\left[{ }^{32} \mathrm{P}\right]$ oct in the presence of mRNA, its 11-17th sucrose gradient fractions exhibited a lower level of specific labelling due to competition (Fig. 4, B). Thirdly, when the 30S-RSU sample was incubated with $\left[{ }^{32} \mathrm{P}\right]$ oct in the presence of mRNA accompanied by $\mathrm{IF}_{1}$, $\mathrm{IF}_{2}, \mathrm{IF}_{3}$, and fMet-tRNA, its 11-17th sucrose gradient fractions exhibited a level of specific labelling which was lower (Fig. 4, $C$ ) than that observed in Fig. 4, A, but higher than that observed in Fig. 4, $B$. Thus, the presence of IFs and fMet-tRNA compensated to a significant extent the effect of competition exerted by 



Fig. 4. Interaction of $\left[{ }^{32} \mathrm{P}\right]$ oct with $16 \mathrm{~S}$ rRNA and its competition with 002 mRNA in the absence and in the presence of IFs and fMet-tRNA. A 10-30\% sucrose gradient was performed in Nierenberg buffer containing, in $10 \mathrm{mM}$ Tris- $\mathrm{HCl}$ at $\mathrm{pH} 7.7,10 \mathrm{mM}$ magnesium acetate and $60 \mathrm{mM} \mathrm{NH} \mathrm{N}_{4} \mathrm{Cl}$ at $\mathrm{pH}$ 7.7. Centrifuging through this gradient lasted $2 \mathrm{hrs}$ at 40,000 rev./min in the rotor TST 60.4 of the Kontron. (A) Incubation of 100 pmoles of 30 S RSUs with 200 pmoles of $\left[{ }^{32} \mathrm{P}\right]$ oct. $(B)$ Incubation of 50 pmoles of $30 \mathrm{~S}$ RSUs with 100 pmoles of $\left[{ }^{32} \mathrm{P}\right]$ oct and 100 pmoles of unlabelled mRNA. (C) Incubation of 50 pmoles of 30S RSUs with 100 pmoles of $\left[{ }^{32} \mathrm{P}\right]$ oct, 100 pmoles of unlabelled mRNA and 50 pmoles of unlabelled $\mathrm{IF}_{1}, \mathrm{IF}_{2}, \mathrm{IF}_{3}$, and fMet-tRNA. The fractions were $200 \mathrm{ml}$ each: the first corresponded to the bottom of the centrifuge tube; the last corresponded to its top. Filled circles: OD at $260 \mathrm{~nm}$. Empty circles: amount of the captured $\left[{ }^{32} \mathrm{P}\right]$ oct. The experiments were repeated three times for $(A)$ and two times for $(B)$ and $(C)$

mRNA in hybridizing the almost fully available anti-SD sequence of $16 \mathrm{~S}$ rRNA.

Partial availability of the anti-SD sequence in $70 \mathrm{~S}$ ribosomes. The access to the anti-SD sequence of $16 \mathrm{~S}$ rRNA, in the entire $70 \mathrm{~S}$ ribosomes, was appreciably reduced when compared to the situation characterizing the 30S RSUs. This emerged from a new analysis showing that, if the 70S-ribosomal sample was incubated with $\left[{ }^{32} \mathrm{P}\right]$ oct only, its $7-15$ th sucrose gradient fractions carried a modest amount of specific radioactivity (Fig. 5, A). Instead, the 7-15th $70 \mathrm{~S}$ sucrose gradient fractions exhibited a smaller amount of specific radioactivity if, in hybridizing the anti-SD sequence of $16 \mathrm{~S}$ rRNA, a competition occurred between $\left[{ }^{32} \mathrm{P}\right]$ oct and mRNA (Fig. 5, B). On the other hand, the level of specific radioactivity in the $7-15$ th $70 \mathrm{~S}$ sucrose gradient fractions was even lower when the $70 \mathrm{~S}$ ribosomes were incubated with $\left[{ }^{32} \mathrm{P}\right]$ oct in the presence of mRNA and fMet-tRNA (Fig. 5, C). This level did not change too much when the 70S ribosomes were incubated with $\left[{ }^{32} \mathrm{P}\right]$ oct in the presence of mRNA accompanied by fMet-tRNA and Phe-tRNA (Fig. 5, D). In sum, in all four cases, the availability of the anti-SD sequence of $16 \mathrm{~S}$ rRNA had to be considered as partial in $70 \mathrm{~S}$ ribosomes.

Inaccessibility of the anti-SD sequence in polysomes. At variance with the differential specific labelling of 30S RSUs (Fig. 4) and 70S ribosomes (Fig. 5), the 2-9th sucrose gradient fractions, having polysomes, did not exhibit any radioactivity if incubated with $\left[{ }^{32} \mathrm{P}\right]$ oct (Fig. 6). This demonstrated that the polysomal structure did not expose the anti-SD sequence of $16 \mathrm{~S}$ rRNA to the labelled octamer.

The assumption that in bacteria the SD/anti-SD hybrid might be maintained not only at the early stages of translation but also during elongation had to be further verified [16]. If we consider that (i) the SD interaction influences the ribosomal frame-shifting [8], (ii) the SD base pairing stabilizes the mRNA/ribosome interaction also during the first round of translation elongation [9], (iii) the hydroxyl-radical footprinting shows that protection of the SD sequence by the ribosome still persists in the $\ll 70 \mathrm{~S} / \mathrm{mRNA} / \mathrm{fMet}-$ tRNA/Phe-tRNA» elongation complex [9], we may state that this background information was consistently in harmony with the findings provided herewith. For the sake of clarity, the first result showed that the anti-SD sequence of 16S rRNA was highly available in 30 S RSUs, since about $65 \%$ of these were able to bind $\left[{ }^{32} \mathrm{P}\right]$ oct. In this case, the presence of equimolar amounts of 002 mRNA, carrying the SD sequence, led 

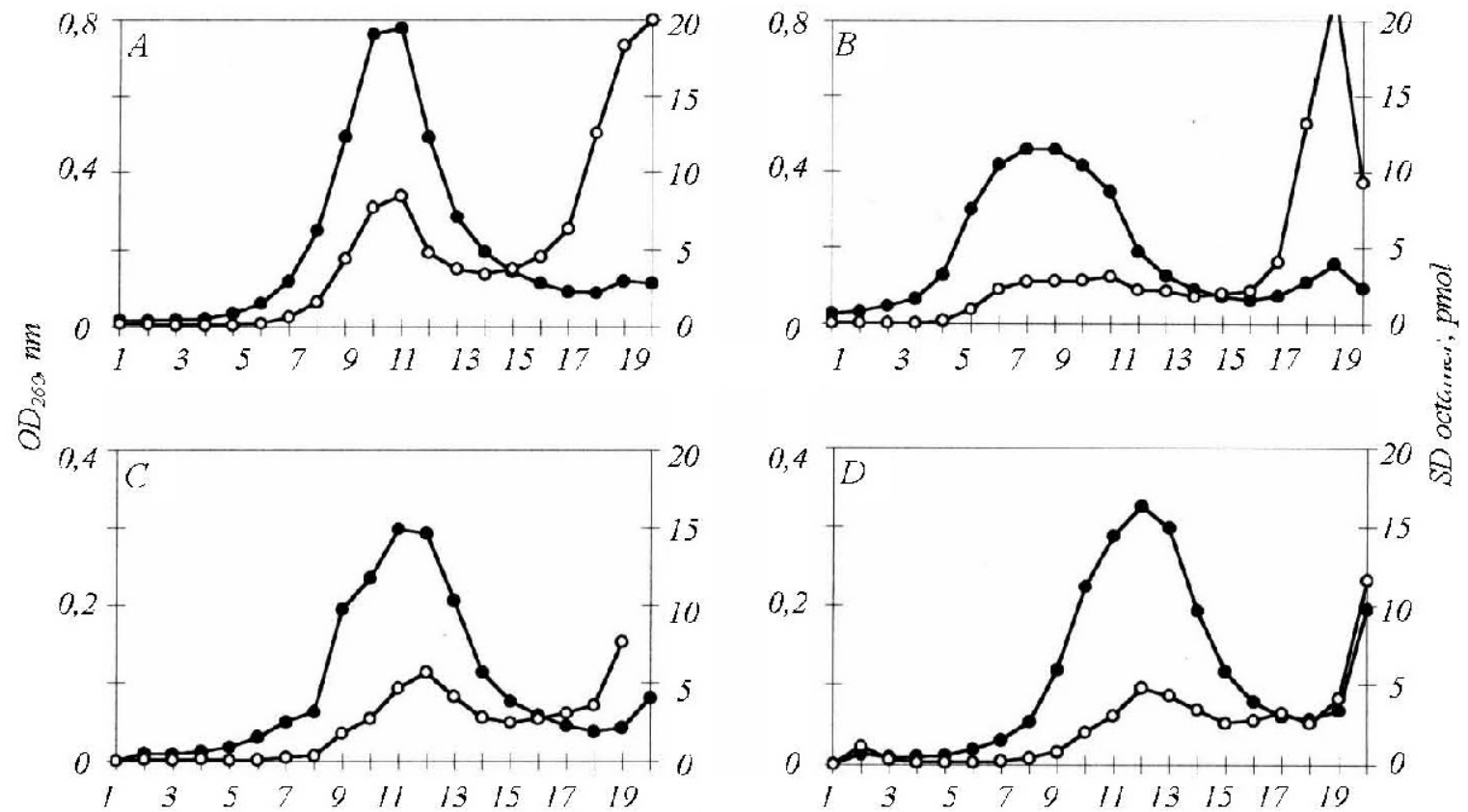

Fraction namber

Fig. 5. Interaction of $\left[{ }^{32} \mathrm{P}\right]$ oct with $70 \mathrm{~S}$ ribosomes and its competition with $002 \mathrm{mRNA}$. The analysis through sucrose gradient was performed as for Fig. 4. (A) Incubation of 100 pmoles of $70 \mathrm{~S}$ ribosomes with 200 pmoles of $\left[{ }^{32} \mathrm{P}\right]$ oct. $(B)$ Incubation of 100 pmoles of $70 \mathrm{~S}$ ribosomes with 200 pmoles of $\left[{ }^{32} \mathrm{P}\right]$ oct and 200 pmoles of unlabelled mRNA (competition of $\left[{ }^{32} \mathrm{P}\right]$ oct with mRNA for the binding with the $70 \mathrm{~S}$ ribosomes). (C) Incubation of 100 pmoles of $70 \mathrm{~S}$ ribosomes with 200 pmoles of $\left[{ }^{32} \mathrm{P}\right]$ oct, 200 pmoles of unlabelled mRNA and 100 pmoles of unlabelled fMet-tRNA (competition of $\left[{ }^{32} \mathrm{P}\right]$ oct with mRNA for the binding with the 70S ribosomes in the presence of fMet-tRNA). $(D)$ Incubation of 100 pmoles of $70 \mathrm{~S}$ ribosomes with 200 pmoles of $\left[{ }^{32} \mathrm{P}\right]$ oct, 200 pmoles of unlabelled mRNA and 100 pmoles of unlabelled fMet-tRNA and Phe-tRNA (competition of $\left[{ }^{32} \mathrm{P}\right]$ oct with mRNA for the binding with the 70S ribosomes in the presence of fMet-tRNA and Phe-tRNA). Filled circles: OD at $260 \mathrm{~nm}$. Empty circles: amount of the captured $\left[{ }^{32} \mathrm{P}\right]$ oct. The experiments were repeated three times for $(A)$ and two times for $(B),(C)$, and $(D)$

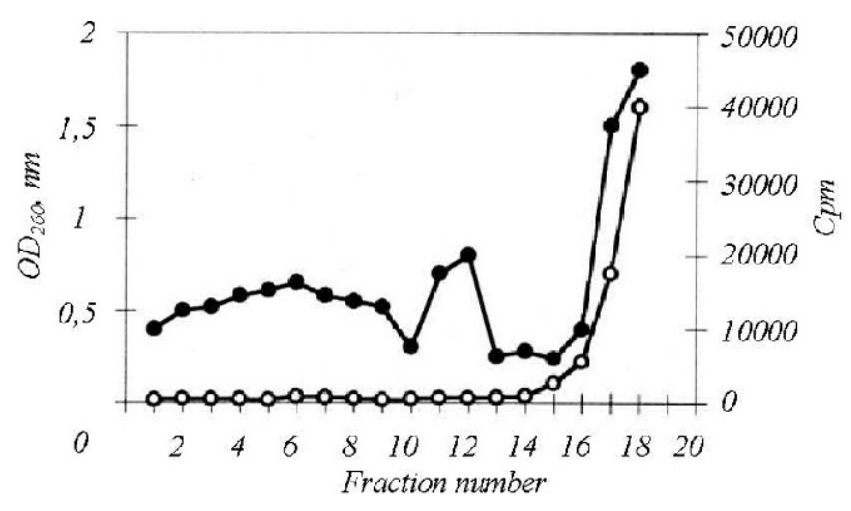

Fig. 6. Interaction between $\left[{ }^{32} \mathrm{P}\right]$ oct and polysomes. 100 pmoles of polysomes were incubated with 200 pmoles of $\left[{ }^{32} \mathrm{P}\right]$ oct. The analysis through sucrose gradient was performed as for Fig. 4 and 5. Filled circles: OD at $260 \mathrm{~nm}$. Empty circles: radioactivity of captured $\left[{ }^{32} \mathrm{P}\right]$ oct. The experiment was repeated twice

to the binding of about $15 \%$ of $\left[{ }^{32} \mathrm{P}\right]$ oct. The second result showed that in the entire $70 \mathrm{~S}$ ribosomes, the
anti-SD sequence of $16 \mathrm{~S}$ rRNA was still available, although to a lesser extent, since about $50 \%$ of $70 \mathrm{~S}$ ribosomes was able to bind $\left[{ }^{32} \mathrm{P}\right]$ oct. Moreover, the presence of IFs plus fMet-tRNA induced a small increase of bound $\left[{ }^{32} \mathrm{P}\right]$ oct in $70 \mathrm{~S}$ ribosomes while the presence of fMet-tRNA plus Phe-tRNA (the first tRNA needed for elongation) induced a slight percentage increase of bound $\left[{ }^{32} \mathrm{P}\right]$ oct in them. Thus, in these conditions, the SD sequence at the 5'-end of mRNA was not yet detached from the 3 '-end of $16 \mathrm{~S}$ rRNA. The third result concerned the polysomes. In them the anti-SD sequence of all ribosomes was shown to be fully inaccessible. This fact generated two hypotheses: (i) in polysomes, the anti-SD sequence of the first leader ribosome - would continue to be involved in hybridization with the SD sequence of mRNA; (ii) in polysomes, the anti-SD sequence of the successive ribosomes would be masked by conformational changes abolishing its capability to attract $\left[{ }^{32} \mathrm{P}\right]$ oct. The latter alternative might have, in the prokaryotic world, 
some bearing with the cell-cycle dependent conformational changes of the eukaryotic polysomal structure [17]. Similarly, conformational changes of polysomes in prokaryotes might cause non-availability of the anti-SD sequence carried by $16 \mathrm{~S}$ rRNA to be recognized by the SD sequence carried by mRNA.

Conclusion. Although with quantitative differences, the access to the anti-SD target of $16 \mathrm{~S}$ rRNA was shown to be always «open» in both $30 \mathrm{~S}$ RSUs and 70S ribosomes, while the anti-SD target of $16 \mathrm{~S}$ rRNA appeared to be completely «closed» in polysomes. On this basis, we assumed that the $\mathrm{SD} /$ anti-SD hybrid is maintained from the time of formation of the first peptide bond up to the time of release of the encoded polypeptide. Such an important suggestion deserves attention also in connection with the idea that the same mRNA - with its SD sequence might regulate accessibility. This does not exclude that any variation of polysomal conformation, correlative with mRNA length [17], would influence the speed of the ribosomal movement along it [18] and, ultimately, the translational rate essentially [17].

Acknowledgements. Sincere gratitude is expressed to T. Eremenko, of the former Institute of Experimental Medicine, CNR, Rome, for advice and precious help in providing a number of facilities for this study. Many thanks are also due to E. Bertoli, of the Institute of Biochemistry of the University of Ancona, for valuable encouragement. The investigation was supported by the University of Rome «Tor Vergata», the University of Ancona, the Ministry of the University and Scientific and Technological Research and the National Research Council.

\section{REFERENCES}

1. Gualerzi C. O., Pon C. L. Initiation of mRNA translation in prokaryotes // Biochemistry.-1990.-29.- P. 5881-5889.

2. McCarthy J., Gualerzi C. O. Translational control of prokaryotic gene expression // Trends Genet.-1990.-6.P. 78-85.

3. Shine J., Dalgarno L. The 3'-terminal sequence of Escherichia coli $16 \mathrm{~S}$ ribosomal RNA: Complementarity to nonsense triplets and ribosome binding sites // Proc. Natl. Acad. Sci. USA.-1974.-71.-P. 1342-1346.
4. Hui A., de Boer H. A. Specialized ribosome system: preferential translation of a single mRNA species by a subpopulation of mutated ribosomes in Escherichia coli // Proc. Natl. Acad. Sci. USA.-1987.-84.-P. 4762-4766.

5. Jacob W. F., Santer M., Dahlberg A. E. A single base change in the Shine-Dalgarno region of $16 \mathrm{~S}$ rRNA of Escherichia coli affects translation of many proteins // Proc. Natl. Acad. Sci. USA.-1987.-84.-P. 4757-4761.

6. Melancon P., Leclerc D., Destroismaisons $N$., Brakier-Gingras $L$. The anti-Shine-Dalgarno region in Escherichia coli $16 \mathrm{~S}$ ribosomal RNA is not essential for the correct selection of translational starts // Biochemistry.-1990.-29.-P. 3402-3407.

7. Calogero R. A., Pon C. L., Canonaco M. A., Gualerzi C. O. Selection of mRNA translation initiation region by Escherichia coli ribosomes // Proc. Natl. Acad. Sci. USA.-1988.-85.-P. 6427-6431.

8. Huttenhofer A., Noller H. F. Footprinting mRNA-ribosome complexes with chemical probes // EMBO J.-1994.-13.P. 3892-3901.

9. Wiess R. B., Dunn D. M., Dahlberg A. E., Atkins J. F., Gesteland R. F. Reading frame switch caused by base-pair formation between the 3 '-end of $16 \mathrm{~S}$ rRNA and the mRNA during elongation of protein synthesis in Escherichia coli // EMBO J.-1988.-7.-P. 1503-1507.

10. Duranti T., La Teana A., Cacciamani T., Volpe P. The prokaryotic origin of the pathways for synthesis and post-synthetic modification of DNA // RNA Biol.-2006.-3.P. 49-53.

11. Godson G. N. A technique of rapid lysis for the preparation of Escherichia coli polyribosomes // Meth. Enzymol.-1967.12A.-P. 503-516.

12. Ohsawa H., Gualerzi C. O. Chemical modification of Escherichia coli $30 \mathrm{~S}$ ribosomal proteins by the site-specific reagent pyridoxal phosphate: inactivation of the aminoacyl-tRNA and mRNA binding sites // J. Biol. Chem.-1983.-258.-P. 150-156.

13. Gualerzi C. O., La Teana A., Spurio R., Canonaco M. A., Severini M., Pon C. L. Initiation of protein biosynthesis in prokaryotes: recognition of mRNA by ribosomes and molecular basis for the function of initiation factors // The ribosome. Structure, function and evolution / Eds W. E. Hill, A. Dahlberg, R. A. Garrett, P. B. Moore, D. Schlessingedr, J. R. Warner.-Washington: DC, Am. Soc. Microbiol. Publ., 1990.-P. 281-291.

14. Dubendorff J. W., Studier F. W. Creation of a T7 autogene. Cloning and expression of the gene for bacteriophage T7 RNA polymerase under control of its cognate promoter // J. Mol. Biol.-1991.-216.-P. 61-68.

15. Sambrook J., Fritsh E. F., Maniatis T. Molecular cloning. A laboratory manual.-New York: Cold Spring HLQB, 1989.

16. Maraschio D., La Teana A., Volpe P. Protein biosynthesis in prokaryotes: probing the path of the mRNA during translation // Transact. Ital. Biochem. Soc.-1997.-9.-P. 264.

17. Eremenko T., Volpe P. Polysome translational state during the cell cycle // Eur. J. Biochem.-1975.-52.-P. 203-210.

18. Papaphilis $A$. D. On the rate of ribosome translocation. Anisotropy and ribosome saturation in the polysome // J. Theor. Biol.-1973.-38.-P. 613-625. 